\title{
The Criminal Liability of the Compliance Officer: An Approach Through Several Hard Cases
}

\section{La Responsabilidad Penal del Compliance Officer: Una Aproximación a Través de Algunos Casos Difíciles}

\section{Víctor Gómez MARTIN ${ }^{1}$ (1)}

${ }^{1}$ Prof. Dr. Law Faculty University of Barcelona, Spain

ORCID: V.G.M. 0000-0002-3302-6210

\section{ABSTRACT}

There is broad consensus in the academic legal opinion that traditional theories on perpetration and participation are insufficient to determine criminal liability in complex organisational structures, in particular in the business sector. Corporate activity rarely takes place through the implementation of naturalistic actions; it is more often a matter of adopting agreements reached by management bodies. Consequently, when determining perpetration, the decisive element is displaced from actual commission to the taking of strategic decisions, or even failure to avoid the criminal conduct committed by a third party. In this context, it is hardly surprising that particular relevance falls upon the attribution of liability for commission by omission. This would also be motivated by reasons of a practical nature: without evidence of actual commission of the offence, it would doubtlessly be easier to attest that the crime committed by someone lower down in the hierarchy had taken place in the sphere of competence of a hierarchical superior (administrator or senior manager) who, though able to prevent it, failed to do so. Based on this twofold premise, this paper sets out to reflect upon one of the new corporate subjects arising out of the reforms introduced by Organic Laws $5 / 2010$ and $1 / 2015$ in the field of criminal liability of legal persons and crime prevention models (corporate criminal compliance): the compliance officer.

Keywords: Compliance officer, criminal compliance programs, economic criminal law, delegation, duties of supervision, surveillance and control

\section{ABSTRACT (versión española)}

Existe consenso doctrinal en torno a la idea de que las teorías tradicionales de la autoría y la participación devienen insuficientes para la determinación de la responsabilidad penal en estructuras organizativas complejas, en particular en el ámbito empresarial. Con carácter general, el desarrollo de la actividad propia de la corporación no tiene lugar a través de la implementación de acciones naturalísticas, sino por medio de la adopción de acuerdos por parte de los órganos de dirección. En consecuencia, el elemento decisivo para la determinación de la autoría se desplaza de la ejecución material a la toma de decisiones estratégicas o, incluso, a la no evitación de la ejecución de la conducta típica por parte de un tercero. En este contexto, no es de extrañar que cobre particular relevancia la atribución de responsabilidad en comisión por omisión. Ello también obedecerá a razones de naturaleza práctica: en defecto de prueba de la ejecución material del delito resultará sin duda más sencillo acreditar que el hecho delictivo cometido por un inferior jerárquico habría tenido lugar en la esfera de competencia del superior (administrador o alto directivo) que, habiendo podido evitarlo, no lo hizo. Partiendo de esta doble premisa, el objeto de las líneas que siguen es reflexionar sobre uno de los nuevos sujetos corporativos a propósito de las reformas operadas por las LLOO 5/2010 y 1/2015 en materia de responsabilidad penal de personas jurídicas y modelos de prevención de delitos (compliance penal): el compliance officer o encargado de cumplimiento.

Submitted: 02.04 .2020 • Revision Requested: 15.05.2020 • Last Revision Received: 27.05 .2020 • Accepted: 28.05 .2020 •

Corresponding author: Víctor Gómez Martín, E-mail: victor.gomez@ub.edu

Citation: Martín, VG. 'The Criminal Liability of the Compliance Officer: An Approach Through Several Hard Cases' (2020) 8(1) Ceza Hukuku ve Kriminoloji Dergisi-Journal of Penal Law and Criminology, 59. https://doi.org/10.26650/JPLC2020-0010 


\section{The Compliance Officer: A Brief Presentation}

Article 31 bis, paragraph 2 of the Spanish Criminal Code provides that: "If the offence was committed by the persons referred to in letter a) of the previous sub-section, the legal person shall be exempt from liability if the following requirements are met: (...); 2nd: The supervision of the performance and compliance of the prevention model introduced has been entrusted to a body of the legal person with independent powers of initiative and control or which has been legally entrusted with the task of supervising the efficiency of the internal controls of the legal person". Other than this generic reference, there is no legal text regulating the figure of the compliance officer. Neither the professional profile, nor the structure, nor the duties or position in the company of this person is governed by legislation. ${ }^{1}$

Given the situation, it should come as no surprise that Spanish companies are implementing the compliance body in very different ways. Some choose to appoint an individual, internal or external compliance officer. Others make a distinction between compliance body and compliance officer. The former would take the form of an Ethics Committee, while the functions of the latter would be physically assumed by the company's legal department. Various companies have implemented yet another system through the constitution of a Compliance Committee. This body is coordinated by the compliance officer and made up of members from the Legal and Human Resources departments, while also receiving support from the Internal Audit and Strategic Planning departments. In all of these models, the compliance officer is characterised by an essentially legal profile, which on occasions may entail evident conflicts of interest.

Some companies establish the compliance officer as a member of senior management, with executive powers, in other words, authority and organisational competencies in company activity. In such cases the post-holder's hierarchical position must be high

1 This circumstance is highlighted in Ricardo Robles "El responsable de cumplimiento - 'compliance officer' - ante el Derecho penal”, in Jesús Silva (Dir.) / Raquel Montaner (Coord.), Criminalidad de empresa y compliance. Prevención y reacciones corporativas (2013), 320; Jacobo Dopico, "Posición de garante del compliance officer por infracción del "deber de control: una aproximación tópica", in Santiago Mir / Mirentxu Corcoy / Víctor Gómez (Dirs.) / Juan Carlos Hortal / Vicente Valiente (Coords.), Responsabilidad de la empresa y Compliance. Programas de prevención, detección y reacción penal (2014), 518; Juan Antonio Lascuraín, "Salvar al oficial Ryan (sobre la responsabilidad penal del oficial de cumplimiento)", in Santiago Mir / Mirentxu Corcoy / Víctor Gómez (Dirs.) / Juan Carlos Hortal / Vicente Valiente (Coords.) Responsabilidad de la empresa y Compliance. Programas de prevención, detección y reacción penal (2014), 303; Raquel Montaner, "El Criminal compliance desde la perspectiva de la delegación de funciones", in Ramón Ragués / Ricardo Robles (Dirs.), Delito y empresa. Estudios sobre la teoría del delito aplicada al Derecho penal económico-empresarial, (2018), 69; Alejandro Turienzo, Principios de imputación en las relaciones horizontales. A propósito del órgano colegiado de cumplimiento (unpublished original), 2. 
enough for him or her to seek and receive full collaboration from other members of the organisation. It is therefore understandable that, in comparative terms, the position of compliance officer is often deemed equivalent to one of senior or, to a lesser extent, middle management. In these circumstances, the compliance officer who could prevent an offence of which they have knowledge - for example, by correcting the wrongful act being committed by an employee or directly dismissing the individual - but fails to do so, could be considered co-perpetrator of the crime committed by the material author.

In this competency model, regardless of whether he or she forms part of senior or middle management (deputy or assistant to senior management), the compliance officer must be considered a delegate, in the strictest sense, of the Board of Directors. By virtue of such delegation, the post-holder becomes the principal guarantor and the administration body the secondary guarantor, with mere duties of oversight. ${ }^{2}$

Nonetheless, it will be most often the case that the compliance officer will be given informative or advisory functions in the framework of an area of competence usually dependent on the financial or administration department. It is with good reason that the figure of the compliance officer is generally considered compatible with other already existing positions with competences in the field of control, such as that of the data protection officer (DPO). In this case, liability for non-prevention of an offence will correspond with that of an accessory, provided the breach of his or her professional duties facilitates commission of the crime.

\section{Criminal Liability Of The Compliance Officer: A Case Study}

\subsection{Premises}

Compliance officers may be held liable as the perpetrator of an offence committed by another which they have not prevented, provided their position is one of guarantor. To occupy such a position, it will be necessary that the officer in question is a delegate of the company in relation to a duty of guarantee of same. ${ }^{3}$ If, as is usual, he or she cannot be considered guarantor, either because the company is not in that position in relation to the particular offence, or because he or she is not a delegate of that company, the compliance officer may still be held criminally liable as an accessory to a corporate

2 Jacobo Dopico (n 1), 516; José Antonio Lascuraín, "Fundamento y límites del deber de garantía del empresario", en Luís Arroyo (Dir.), Hacia un Derecho penal económico europeo. Jornadas en honor del Profesor Klaus Tiedemann (1995), 218 ff.; Eduardo Demetrio, Responsabilidad penal por omisión del empresario (2009), $107 \mathrm{ff}$.

3 Juan Antonio Lascuraín (n 1), 325 f. 
crime if the breach of his or her duties enabled the crime to be committed. ${ }^{4}$ In any case, to make the compliance officer accountable for commission by omission, the risk of engagement in an offence that was not prevented must belong to the type of risks whose oversight commitment was previously explicitly and specifically adopted by the post-holder. As a general rule, it will also be necessary for a member of the company to commit a crime with intent (dolus eventualis) and for the compliance officer's acts of omission to be intentional, as a good deal of offences committed in the context of company activity cannot be categorised in Spanish Criminal Code (CC) under the heading of negligence. ${ }^{5}$

Criminally relevant conduct of the compliance officer would usually consist in the omission of actions that would avoid the crime being committed, inactivity when faced with indications or suspicion of an offence and non-transmission of relevant information to company management. An example of the latter would be blocking the complaint lodged against a company member regarding the possible commission of a crime. ${ }^{6}$ Nonetheless, eventual criminal liability of the compliance officer will require that the referred crime has not yet been committed. ${ }^{7}$ If it has already been perpetrated, the compliance officer could, purely hypothetically, answer to the offence of breach of the duty to report crimes. However, such possibility would be flatly rejected, because Art. 408 CC punishes the "authority or public officer who, failing in the obligations of his office, were to intentionally cease to promote persecution of the offences that he or his officers obtain knowledge of". The special legal duty whose breach would constitute an offence would link the authority or public officer to the State, without any possibility of extending it to the compliance officer, beyond the commitment the latter has assumed with his or her company. ${ }^{8}$ In the case of private individuals, failure to report can only be

\footnotetext{
4 Juan Antonio Lascuraín (n 1), 326.

5 Carolina Bolea, "Delegación de funciones. deberes de control y vigilancia", in Mirentxu Corcoy / Víctor Gómez (Dirs.), Manual de Derecho penal económico y de empresa, PG y PE (adaptado a las LLOO 1/2015 y 2/2015 de Reforma del Código Penal). Doctrina y jurisprudencia con casos solucionados, II (2015), 73.

6 Ricardo Robles (n 1), 325; Mateo Germán Bermejo / Omar Palermo, "La intervención delictiva del compliance officer", in Lothar Kuhlen / Juan Pablo Montiel / Iñigo Ortiz de Urbina (Dirs.), Compliance y teoría del delito (2013), 197; Jacobo Dopico (n 1), 525 f.; Ídem "Presupuestos básicos de la responsabilidad penal del «compliance officer» tras la reforma penal de 2015", in Frago Amada (Dir.), Actualidad Compliance (2018) $225 \mathrm{f}$.

$7 \quad$ Ricardo Robles (n 1), $325 \mathrm{f}$.

8 Jacobo Dopico (n 1), $531 \mathrm{f}$.
} 
criminal when it is not preventing certain crimes (Art. 450.1 CC). ${ }^{9}$ Accordingly, the only criminal liability that can be imputed to the compliance officer who fails to submit a complaint for a crime already committed is that of covering up the offence (Art. 451 CC) or receiving stolen goods (Art 298.1 CC). ${ }^{10}$

Another situation involving the hypothetical criminal liability of compliance officers would be determined by the specific range of criminal risks they explicitly assume. ${ }^{11}$ In this context, it is worth remembering that delegation to the compliance officer of oversight of all the risks inherent in the company's activity is not common practice. Only certain risks are transferred, in particular fraudulent offences (fraud, misappropriation, criminal bankruptcy, tax evasion and Social Security fraud, etc.), and crimes of corruption (bribery, influence peddling, corruption between private individuals, etc.). ${ }^{12}$ Safeguarding against other risks, such as those relating to money laundering, the environment and safety at work are usually delegated to specialised services or departments. It is the people that make up these services, rather than those of the company's general compliance body, who will be liable for not preventing risks connected with these sectorial fields of competences that materialise in criminal damage to criminal legal goods. ${ }^{13}$

Finally, as the person responsible for the oversight and control of the crime prevention model, the compliance officer's duty to the company ends with his or her effective fulfilment of that role. Once the company has been informed of an indication that a crime will possibly be committed, and given the usual supposition that executive powers have not been assigned to the compliance officer, the compliance body is not obliged to adopt other measures (for example, set in motion an internal investigation

9 Ricardo Robles (n 1), 325; Raquel Montaner (n 1), 84; idem, "El compliance officer y el Código penal", in Jorge Navarro (Dir.) / Raquel Montaner (Coord.), El compliance officer, ¿un profesional en riesgo?, (2018), 32. In a similar vein in the context of German legislation, Jürgen Bürkle, "Grenzen der strafrechtlichen Garantenstellung des Compliance-Officers", $C C Z$ 1/2010, 10 f.; Werner Beulke, "Der "Compliance Officer" als Aufsichtsgarant? Überlegungen zu einer neuen Erscheinungsform der Geschäftsherrenhaftung", in Festschrift für Klaus Geppert zum 70. Geburtstag am 10. März (2001), 23 ff.; Thomas Rönnau / Frédéric Schneider, "Der Compliance-Beauftragte als strafrechtlicher Garant", ZWH; Vol. 2, (2010); Nadja Raus / Martin Lützeler, "Berichtspflicht des Compliance Officers - zwischen interner Eskalation und externer Anzeige", $C C Z 3 / 2012,97$. Alejandro Turienzo (n 1), 16, reaches identical conclusions in relation to cases of absence of complaint ad intra by the sectorial compliance officer with respect to the offence committed by another sectorial compliance officer in the framework of the sphere of competences of the latter, of which the former may have had knowledge.

10 About this possibility, Raquel Montaner (n 9), $32 \mathrm{f}$.

11 Mateo Germán Bermejo / Omar Palermo (n 6), 188.

12 Ricardo Robles (n 1), 325.

13 Ricardo Robles (n 1), 326; Jacobo Dopico (n 1), 527. 
or order dismissal of the person suspected of the offence) to prevent the crime from being or continuing to be committed. ${ }^{14}$ In this event the compliance officer has been assigned such executive authority - which would, we insist, be exceptional- and is presented with rational indications of criminality in the company, failure to initiate an internal investigation with the intention of not obstructing commission of the crime would be considered participation by omission in an offence committed by another. ${ }^{15}$ This would also apply in the case of preprogrammed or routine investigations provided, of course, that the compliance officer has been made aware of the commission of an offence by a third party. ${ }^{16}$

Once informed by the compliance officer, the administration body, or other department which should receive the information in accordance with the crime prevention model, fail to implement the corrective actions proposed, precisely what the compliance officer should do next is somewhat unclear. In systems like that of Germany, in which the channelling of reports of infringements in the company must be carried out through the Ombudsman or Vertrauensanwalt, or the Italian structure in which the compliance body is represented by the organismo di vigilanza, the compliance officer must file a report on the matter with these organisations to remain free from all liability. The only exception to this approach would be, given the case, the general duty to report certain offences if they have not yet been committed. However, it is doubtful that such duties could be easily extrapolated to the Spanish system. ${ }^{17}$

\subsection{Liability of the compliance officer for ordinary offences}

\section{a) Afew methodological premises}

In those circumstances in which criminal liability may be attributed to the compliance officer for an ordinary offence it is necessary to ask whether such liability should be considered as perpetration or participation. ${ }^{18}$ Logically, the answer to this question will depend on the criteria deemed preferable to determine perpetration in criminal law. ${ }^{19}$

\footnotetext{
14 Ricardo Robles (n 1), 326.

15 Jacobo Dopico (n 1), 529.

16 Jacobo Dopico (n 1), 529.

17 Jesús Silva, "Bases de la responsabilidad penal de los administradores de sociedades mercantiles", in Fundamentos del Derecho penal de la empresa (2013), 199; Ídem, "Deberes de vigilancia y Compliance empresarial”, in Lothar Kuhlen / Juan Pablo Montiel / Iñigo Ortiz (Dirs.) (n 6), 104. In a similar sense Jacobo Dopico (n 6), 231.

18 Clara Blanc, La responsabilidad penal del Compliance officer (2017), $371 \mathrm{ff}$.

19 Ricardo Robles (n 1), 327.
} 
The perspective of the theory of control over the act and, more specifically, control over the organisation, considers that the person who has control over the risks inherent in the business activity has control over the business as a whole. This control extends to all levels of the organisation and, thus, to the company management. The compliance officer would form part of the group of individuals who, being able to intervene in the offence, would do so without control over the act, in other words, from the position of accessory that results from participating in a crime. In this context it could, at most, be argued that the compliance officer has potential control over the act, which is obviously insufficient for an accusation of perpetration. However, for those offences that may be conceived as culpable breach of duty, only in the case where the duty to prevent crimes in the company falls upon the compliance officer could he or she be considered perpetrator of the crime that was not avoided. As previously stated, this scenario is highly unlikely, as it would mean granting the compliance officer executive powers within the company which as a general rule such positions never have. ${ }^{20} \mathrm{Of}$ these two notions of perpetration, this research considers the first to be preferable.

It should also be remembered that, excepting the infrequent cases in which breach of the duties assigned to the compliance officer materialises as the active commission of an offence, possible criminal liability of this agent would usually be explained as by omission. The traditional notion defended in its day by Armin Kaufmann and predominantly followed thereafter by academic legal opinion holds that there are two possible material sources of the positions of guarantor: existence of a function of protection of the legal good and the concurrence of a duty of control of a source of danger. ${ }^{21}$ Of these two sources of the guarantor's position, in the area of crimes committed in the context of a legal person the prevailing academic legal opinion usually considers - as previously noted - that company management occupies the position of guarantor. That body is therefore obliged to organise the different levels of the business to ensure crimes are not committed in the company, based on the second of Kaufmann's material sources of the guarantor: the duty of control of a source of danger. According to this notion, the source of danger would be represented by the legal person itself and the duty of control of same would fall upon the members of the company management, in other words, the Board of Directors. In this context, the position of the compliance officer would be merely complementary to that of the administration body, and thus

20 Ricardo Robles (n 1), 327.

21 Armin Kaufmann, Die Dogmatik der Unterlassungsdelikte (1959), passim. 
any possible criminal liability should also be relegated to that which corresponds to accessory to a crime. ${ }^{22}$

\section{b) Groups of cases}

In the light of these general premises, most of the cases in which possible liability of the compliance officer for acting in the sphere of competence of the employer or administrator would be related to the hypothetical offence of breach of the duty to inform the company's senior management. ${ }^{23}$ In this context, distinctions must be drawn between four assumptions of fact.

1) A first group of cases would be represented by those in which, contrary to his or her assigned responsibilities, the compliance officer does not supervise the compliance status of a company department. Certain regulatory infringements would be occurring in this department which, if not corrected in time, would lead to an offence being committed, fraud for example, which would result in criminal liability of the legal person. ${ }^{24}$ In such a case, it might be considered a risk situation in which it could be said that senior management had a specific duty as guarantor to avoid the harmful outcomes that could ensue and that, consequently, proper intervention by the compliance officer would constitute a relevant element in control of the situation. In this event, criminal liability on the part of the compliance officer could be deemed to exist, in general, for participation by omission in the unreported offence. ${ }^{25}$ The compliance officer should also answer as participant by omission if the information omitted were to refer to a criminal activity committed by a subordinate and thus company management would be unable to know about it or adequately exercise the corresponding responsibilities of oversight and control. ${ }^{26}$ In the exceptional circumstance that the compliance officer had recognised executive powers which would enable him or her to avoid commission of the offences, there could be some argument in favour of joint perpetration of the crime between its material author and the compliance officer with whom agreement has been reached not to prevent its commission. ${ }^{27}$

22 Juan Antonio Lascuraín (n 1), 325.

23 Raquel Montaner (n 9), 30.

24 Raquel Montaner (n 9), 30.

25 Raquel Montaner (n 9), $30 \mathrm{f}$.

26 Ricardo Robles (n 1), 329.

27 Mateo Germán Bermejo / Omar Palermo (n 6), 199. 
2) In those cases in which the compliance officer fails to duly provide management with information about indications of a risk situation in the company, senior executives will usually be able to obtain such information by other means. ${ }^{28}$ Naturally, this will depend upon how the crime prevention model is designed in each company, ${ }^{29}$ or more precisely, how the function of the compliance officer is perceived in the specific model in question. In particular, this would refer to the value of the information the compliance officer can contribute for the proper development of the business activity. This relevance will clearly be greater if the compliance officer is established as the sole source of knowledge about the level of regulatory compliance in the company, than if management has other possible channels of oversight and information. ${ }^{30}$ In the latter case, senior managers should answer as accessories to the offence through commission by omission, and the compliance officer or members of the collegial compliance body, as necessary collaborators or accomplices. ${ }^{31}$ This would not be considered criminal perpetration, as could be the case of a hierarchical superior who allows his department's targets to be met through the use of criminal conduct, since the specific employee who commits the offence is not someone who works under the supervision and orders of the person responsible for compliance. ${ }^{32}$

3) Though undoubtedly less frequent, the case could arise in which a compliance officer takes advantage of company management by providing false information, thus ensuring that it too fails to prevent the crime being committed. In these circumstances, the compliance officer could be considered an accessory by using company management, who would have operated as an instrument which acted without criminal intent. ${ }^{33}$

4) Finally, situations can also be imagined in which the administrator tasks the compliance officer with developing and implementing a corruption prevention programme and, rather than fulfil this task, the latter decides to postpone the start-up of the programme. Such postponement would be until a certain financial operation is

28 Ricardo Robles (n 1), 328; Raquel Montaner (n 1), 83, who eventually however is more inclined towards impunity ("[the] compliance officer is a figure who has no independence for the purposes of deciding how to resolve a detected failure to comply with the regulations in the company activity. In this sense (...) the most coherent solution would be to discard his criminal liability, including that of accessory, for the failure to prevent the crimes committed from the company"), with the exception of cases of "intentional adaptation to the criminal conduct of a third party" (86).

29 Mateo Germán Bermejo / Omar Palermo (n 6), 181.

30 Ricardo Robles (n 1), 329. In an identical sense Raquel Montaner (n 1), 82; idem (n 5 ), 30 f.

31 Juan Antonio Lascuraín (n 1), 325.

32 Jacobo Dopico (n 1), $527 \mathrm{f}$.

33 Ricardo Robles (n 1), 328; Raquel Montaner (n 1), 83. 
concluded involving the payment of bribes of which the compliance office is fully aware, the aim being to ensure the operation does not fail. In such a case, if the function of prevention and investigation of corruption offences (and particularly oversight of the actions of others) had been assumed by the compliance officer and no other channels of information existed which might enable prevention of the crime by those with direct competences to do so, Bolea considers that said compliance officer should answer as an accessory to the crime of corruption, with the administrator exempt from punishment. This should be the outcome, provided there was no breach of residual duties of oversight which would include the obligation to detect the corruption risk situation. ${ }^{34}$

\subsection{Liability of the compliance officer in special offences}

With regard to special offences, it may be the case that the compliance officer occupies the position of extraneus [extraneous person, unrelated to the crime]. This would occur, for instance, when a corporate crime is committed for which only the de facto or de jure company administrator can answer as perpetrator, and the compliance officer forms no part of the Board of Directors and cannot be considered the de facto administrator.

Academic opinion on corporate law considers that this will include all others who have exercised such functions on behalf of the company, provided this fact can be duly accredited, or those who present some form of irregularity in their legal situation due to an unaccepted, unregistered or expired defective appointment. ${ }^{35}$ Criminal law doctrine holds that the de facto administrator is anyone who, alone or with others, adopts and imposes the management decisions of a company and, specifically, those expressed in the statutory definitions of a crime. In other words, "whoever is de facto in charge, or governs from the shadows" ${ }^{36}$ In these cases, even though the compliance officer falsely informs company management or fails to provide it with the corresponding information about the investigation of a possible offence, thus causing non-prevention of the commission of the crime which is also committed by the company management, said compliance officer cannot be held accountable as an accessory. In this regard, remember that if special offences are characterised by anything it is precisely by who,

34 Carolina Bolea (n 5), $72 \mathrm{f}$.

35 Silvia Fernández, El administrador de hecho y de derecho. Aproximación a los delitos con restricciones en sede de autoría (2007) passim.

36 Silvia Fernández (n 34). In jurisprudence see, for example, the Spanish Supreme Court ruling STS 816/06, 26-7, FJ $2^{\circ}$. 
through being extraneus, cannot be the direct perpetrator of the criminal offence an accessory or co-perpetrator. ${ }^{37}$

If the actual commission of the special offence is carried out by an extraneus, omission by the compliance officer of actions intended to prevent the crime would, like any possible participatory conduct, be atypical, as would the basic fact that he or she were an accessory. This possible loophole of criminal liability could be resolved if it were to be regarded, as is the case in one sector of academic opinion, that at least some of these offences would not, in fact, be special, but common "by reason of position", and that in same the compliance officer would occupy the position required by the crime of perpetration (for example, that of de facto administrator in corporate crimes). ${ }^{38}$ However, this point of view could be considered questionable for at least two reasons. Firstly, it is doubtful that the solution of the compliance officer as de facto administrator is respectful with the principle of legality and consequently does not incur in the in malam partem analogy [ill will or intention]. Secondly, questions could even be raised about the premise, according to which so-called "crimes by reason of position" would be common crimes, as it would probably be more correct to consider them special, with all the dogmatic consequences that may be extracted from this type of offences. ${ }^{39}$

\section{In Conclusion: The Need for a Protocol of Organisation and Operation of the Compliance Officer}

It must be concluded that the compliance officer should solely answer for any failure to prevent those risks for which responsibility has been specifically transferred from company management to the compliance body. In accordance with that, any crime prevention model that seeks to be effective should include a protocol that regulates the organisation and operation of the compliance officer. This protocol should address the role of leadership, assignment of responsibilities and allocation of resources that correspond to the administration body in the general development of the crime prevention model. It should also define the structure, functions and composition, where applicable, of the Audit, Ethics and Control Committee. With regard to the compliance body in its strictest sense, the protocol must establish the principle of that body's independence, its structure and, finally, the extent of the oversight function of its

37 Ricardo Robles (n 1), 330.

38 Ricardo Robles (n 1), 330.

39 In this sense, see Víctor Gómez, "Delitos de posición y delitos con elementos de autoría meramente tipificadores. Nuevas bases para una distinción necesaria”, RECPC 14-01 (2012), p. 21 ff. 
operation that would correspond to the administration body. The protocol will also be responsible for defining the professional profile, duties and responsibilities of the compliance officer. ${ }^{40}$

Peer-review: Externally peer-reviewed.

Conflict of Interest: The author has no conflict of interest to declare.

Grant Support: Agency for Management of University and Research (AGAUR) of the Government of Catalonia (Spain).

\section{References}

Bermejo. M. G. / Palermo O, "La intervención delictiva del compliance officer", in Kuhlen, L, Montiel JP, Ortiz de Urbina I, (Dirs.), Compliance y teoría del delito (2013).

Beulke, W., "Der "Compliance Officer" als Aufsichtsgarant? Überlegungen zu einer neuen Erscheinungsform der Geschäftsherrenhaftung", in FS-Geppert (2011).

Blanc. C., La responsabilidad penal del Compliance officer (2017).

Bolea, C., "Delegación de funciones. deberes de control y vigilancia", in Corcoy M, Gómez V, (Dirs.), Manual de Derecho penal económico y de empresa, PG y PE (adaptado a las LLOO 1/2015 y 2/2015 de Reforma del Código Penal). Doctrina y jurisprudencia con casos solucionados, II (2015).

Bürkle, J, "Grenzen der strafrechtlichen Garantenstellung des Compliance-Officers", in CCZ (2010).

Demetrio, E., Responsabilidad penal por omisión del empresario (2009).

Dopico J., Presupuestos básicos de la responsabilidad penal del «compliance officer» tras la reforma penal de 2015", in Frago J.A., (Dir.), Actualidad Compliance (2018).

Dopico, J., "Posición de garante del compliance officer por infracción del "deber de control": una aproximación tópica", in Mir S, Corcoy M, Gómez V, (Dirs.) Hortal JC, Valiente V, (Coords.), Responsabilidad de la empresa y Compliance. Programas de prevención, detección y reacción penal (2014).

Fernández, S., El administrador de hecho y de derecho. Aproximación a los delitos con restricciones en sede de autoría (2007).

Gómez, V., "Delitos de posición y delitos con elementos de autoría meramente tipificadores. Nuevas bases para una distinción necesaria", RECPC 14-01 (2012).

Kaufmann, A., Die Dogmatik der Unterlassungsdelikte (1959).

Lascuraín J. A., "Salvar al oficial Ryan (sobre la responsabilidad penal del oficial de cumplimiento)", in Mir S, Corcoy M, Gómez V, (Dirs.) / Hortal JC, / Valiente V, (Coords.), Responsabilidad de la empresa y Compliance. Programas de prevención, detección y reacción penal (2014).

Lascuraín, J.A., "Fundamento y límites del deber de garantía del empresario", en Arroyo L, (Dir.), Hacia un Derecho penal económico europeo. Jornadas en honor del Profesor Klaus Tiedemann (1995).

Montaner R., El compliance officer y el Código penal", in Navarro J. (Dir.) Montaner R, (Coord.), El compliance officer, ¿un profesional en riesgo? (2018).

40 Anna Núñez, "El compliance officer y la empresa", in Jorge Navarro (Dir.) / Raquel Montaner (Coord.) (in 9), (2018) $190 \mathrm{ff}$. A complete model of the regulatory protocol of the organisation and functioning of the compliance body with details of its content may be seen in Jesús Silva, / Ramón Ragués / Víctor Gómez / Raquel Montaner / Beatriz Goena / Anna Núñez, Modelo de prevención de delitos Molins \& Silva Defensa penal, (2017) $192 \mathrm{ff}$. 
Montaner, R., "El Criminal compliance desde la perspectiva de la delegación de funciones", in Ragués R. / Robles, R. (Dirs.), Delito y empresa. Estudios sobre la teoría del delito aplicada al Derecho penal económicoempresarial (2018).

Núñez, A., "El compliance officer y la empresa", in Navarro J, (Dir.) / Montaner R, (Coord.), El compliance officer, ¿un profesional en riesgo? (2018).

Raus, N. / Lützeler, M., "Berichtspflicht des Compliance Officers - zwischen interner Eskalation und externer Anzeige" CCZ (2012).

Robles, R., "El responsable de cumplimiento - 'compliance officer' - ante el Derecho penal”, in Silva JM, (Dir.) Montaner Fernández R, (Coord.), Criminalidad de empresa y compliance. Prevención y reacciones corporativas (2013).

Rönnau, T. / Schneider, F., "Der Compliance-Beauftragte als strafrechtlicher Garant”, ZWH, Vol. 2 (2010).

Silva, J.M. / Ragués, R. / Gómez, V. / Montaner, R. / Goena, B. / Núñez, A., Modelo de prevención de delitos Molins \& Silva Defensa penal (2017).

Silva, J.M., "Bases de la responsabilidad penal de los administradores de sociedades mercantiles", in the same, Fundamentos del Derecho penal de la empresa (2013).

Turienzo, A., Principios de imputación en las relaciones horizontales. A propósito del órgano colegiado de cumplimiento (unpublished original) (2019). 
